\section{Postharvest Shelf Life of Sweet Basil (Ocimum basilicum)}

\author{
Diana D. Lange ${ }^{1}$ and Arthur C. Cameron \\ Department of Horticulture, Michigan State University, East Lansing, \\ MI 48824
}

Additional index words. temperature, postharvest storage, packaging, chilling injury, diurnal response

\begin{abstract}
Shelf life (defined by visual quality) of freshly harvested greenhouse-grown sweet basil was maintained for an average of $\approx 12$ days at $15 \mathrm{C}$. Chilling injury symptoms were severe at storage temperatures of $5 \mathrm{C}$ and below. Shelf life was found to be only 1 and 3 days at 0 and $5 \mathrm{C}$, respectively. Moderate chilling injury was noted at 7.5 and 10C. Harvesting sweet basil later in the day (i.e., 1800 or 2200 нг) increased shelf life by almost $100 \%$ when harvested shoots were held at 10,15 , and $20 \mathrm{C}$, compared to harvesting at 0200 or $0600 \mathrm{HR}$. However, the time of day of harvest did not alter the development of visual chilling injury symptoms or improve shelf life at 0 or $5 \mathrm{C}$.
\end{abstract}

Fresh-cut culinary herbs have become increasingly popular in recent years. Although herb production is expanding to meet this demand, the quality of herbs at the retail market is sometimes unacceptable. One problem is that some fresh herbs are chilling-sensitive, yet are commonly handled with fruits and vegetables. Limited information is available on postharvest storage and handling practices for fresh herbs and on their tolerance to shortterm exposures to chilling temperatures (Hardenburg et al., 1986).

One of the most highly consumed fresh herbs, sweet basil, is sensitive to chilling injury (CI). Saltveit and Morns ( 1990) reported that basil is chilling-sensitive, but did not identify a specific chilling temperature. Joyce et al. (1986) noted that CI symptoms developed at $0 \mathrm{C}$ and suggested that storage at 5 to 7C was optimal for long-term basil storage.

King et al. (1982) found that tomato (Lycopersicon esculentum Mill.) seedlings exposed to chilling temperature in the hours just before dawn were injured far more than seedlings exposed to chilling temperatures between noon and midnight. They proposed that diurnal changes in carbohydrates correlated with chilling sensitivity (King et al., 1988). To our knowledge, no one has yet determined if harvest time during the day could influence subsequent CI of basil.

Retailers often hold sweet basil at room temperature to avoid CI, although these conditions can potentially cause desiccation or en-

\footnotetext{
Received for publication 26 Mar. 1993. Accepted for publication 17 Oct. 1993. Mention of a trademark, proprietary product, or vendor does not constitute a guarantee or warranty of the product by Michigan State Univ. and does not imply its approval over other products or vendors that may also be suitable. The cost of publishing this paper was defrayed in part by the payment of page charges. Under postal regulations, this paper therefore must be hereby marked advertisement solely to indicate this fact.

'Current address: Dept. of Pomology, Univ. of California, Davis, CA 95616.
}

hance growth of decay organisms. No shelf life data for sweet basil at room temperatures have been reported.

The purpose of this study was to characterize visual shelf life of sweet basil as influenced by temperatures from 0 to $25 \mathrm{C}$. In addition, we wished to determine if harvest time during the day would influence subsequent shelf life, development of CI symptoms, or both. In all cases, experiments were conducted with basil packaged in perforated polyethylene to minimize the effect of desiccation on shelf life, as suggested by Joyce et al. (1986).

\section{Materials and Methods}

Sweet basil seeds (Sieger Seed, Imlay City, Mich.) were sown in $11-\mathrm{cm}(600-\mathrm{ml})$ plastic azalea pots with two seeds in each of three holes $\approx 1.5 \mathrm{~cm}$ deep using a commercial peatperlite-vermiculite mix. The seedlings were thinned after 2 weeks to three equally spaced plants per pot. This method of sowing and thinning had been found in preliminary experiments to produce more biomass than one or two plants per pot (data not shown).

Plants were grown in a computer-controlled greenhouse under $24 / 20 \mathrm{C}$ day/night cycles. In all experiments, plants received at least $12 \mathrm{~h}$ of light either naturally or using $400-\mathrm{W}$ high-pressure sodium lamps, and were irrigated weekly with $225 \mathrm{~mm} 20 \mathrm{~N}-20 \mathrm{P}-20 \mathrm{~K}$. Basil shoots were harvested by cutting just below the second fully expanded node from the growing point after $\approx 6$ weeks of growth. Each harvested shoot contained six to eight leaves and weighed 4 to $6 \mathrm{~g}$. Unless otherwise stated, basil shoots with leaves were harvested at $\approx 1400$ HR on sunny days. Harvested shoots were placed in unsealed plastic bags at time of harvest and rapidly transported to the laboratory $(\approx 22 \mathrm{C})$ for packaging.

Two shoots (six to eight leaves each) were sealed per $20 \times 20$-cm package constructed from $127-\mu \mathrm{m}$-thick, low-density polyethylene film (LDF 501, Dow Chemical Co., Midland, Mich.) using a Magneta 620 heat sealer (Packaging Aids Corp., San Francisco). Shoots with bruised or damaged leaves were not used. Four 26.5-gauge needle holes $(\approx 0.4 \mathrm{~mm}$ in diameter) were punched through each package to facilitate $\mathrm{O}_{2}$ and $\mathrm{CO}_{2}$ exchange. The entire procedure of harvesting and packaging took < $90 \mathrm{~min}$ in all experiments (harvesting, 30 rein; packaging, 60 rein). Basil packages were held in darkness under black plastic for the duration of all experiments.

Four packages each of basil were placed in controlled-temperature chambers at $0,5,10$, 15,20 , and $25 \mathrm{C}$, all less than $+1 \mathrm{C}$, and covered with black plastic to maintain darkness. Basil was inspected daily at $1400 \mathrm{HR}$ and rated visually for the presence of necrosis, surface molds, water soaking, chlorosis, and leaf abscission. Shelf life was defined as the time until the first obvious sign of deterioration, based on visual analysis only. The entire experiment was repeated weekly six times beginning in July 1988 and ending in Aug. 1988. The data were pooled and analyzed as a simple two-way analysis of variance (ANOVA) with temperature $\mathrm{x}$ harvest date. The effect of harvest date was not significant.

In a second experiment, packaged sweet basil was held at $0,2.5,5,7.5$, or $10 \mathrm{C}$ for 0,1 , 2, or 3 days before transfer to 20C, with five packages per treatment. Four days from packaging, all basil shoots were analyzed visually for the extent and location of CI symptoms, such as tissue soaking and blackening. Basil cuttings were inspected for any noticeable lesions. This entire experiment was repeated three times. The data were analyzed as a twoway ANOVA with temperature and duration as the main factors.

In a third experiment, sweet basil shoots were harvested every $4 \mathrm{~h}$ beginning at $0200 \mathrm{HR}$ and ending at $2200 \mathrm{HR}$. Shoots were processed and packaged after each harvest as described above, and four packages were placed immediately in controlled chambers set at $0,5,10$, 15,20 , and $25 \mathrm{C}$. The packages were handled and evaluated as described previously, except that observations were made daily at 1600 HR. The entire experiment was conducted three times during Aug. and Sept. 1988, and the data were analyzed as a three-way ANOVA with harvest time, temperature, and harvest date as the main factors.

\section{Results and Discussion}

The average shelf life of packaged sweet basil was longest at $15 \mathrm{C}$ (Table 1), where $>95 \%$ of the packages lasted 7 days or more (Fig. 1). Eight packaged cuttings lasted longer than 13 days, with one cutting lasting 29 days (Fig. 1). The shelf life was eventually limited by the development of surface molds and/or chlorosis of the older tissue. Visual shelf life ranged from 2 to 14 days at 20C, with an average of $>1$ week (Table 1, Fig. 1). At 20C, $50 \%$ of the packages remained visually acceptable for 7 to 9 days. The average shelf life was nearly 1 week (Table 1 ) at $25 \mathrm{C}$, although $60 \%$ of the packages were visually acceptable for 6 days or less.

Shelf life was reduced at temperature $\leq 10 \mathrm{C}$ compared to $15 \mathrm{C}$ (Table 1). Chilling injury 
Table 1. Average shelf life, based on appearance, of packaged sweet basil cuttings as influenced by temperature. Cuttings were harvested at 1600 HR. Mean \pm SD based on 24 packages at each temperature.

\begin{tabular}{lc}
\hline \hline Temp $\left({ }^{\circ} \mathrm{C}\right)$ & Shelf life (days) \\
\hline 0 & $1.6 \pm 0.6$ \\
5 & $3.2 \pm 1.2$ \\
10 & $8.3 \pm 2.7$ \\
15 & $12.5 \pm 5.4$ \\
20 & $7.3 \pm 3.0$ \\
25 & $6.8 \pm 2.4$ \\
\hline
\end{tabular}

symptoms at $10 \mathrm{C}$ were limited to the youngest unexpanded leaves on some of the sweet basil. In these cases, CI was evidenced by watersoaked regions that eventually became necrotic. Shelf life ranged from 3 to 14 days at 10C (Fig. 1), primarily determined by whether or not CI symptoms developed. There was definite evidence of $\mathrm{CI}$ at $5 \mathrm{C}$, and $75 \%$ of the packages was judged unsalable after only 3 days. Chilling injury symptoms were severe at $0 \mathrm{C}$, and the majority of the tissue eventually turned black.

Exposure to 0C for only 1 day, followed by transfer to $20 \mathrm{C}$ for 4 days, caused CI symptoms on $100 \%$. of the packaged sweet basil (Fig. 2). Short-term exposures to $2.5 \mathrm{C}$ also induced CI, although the rate of symptom expression was less than at $0 \mathrm{C}$ (Fig. 2). Three days of exposure at $5 \mathrm{C}$ were required before symptom development limited the salability of the basil. Symptoms developed only after 3 days of exposure to 7.5 or $10 \mathrm{C}$, and affected only $8 \%$ of the packages in both cases (Fig. 2). No further lesions developed after transfer to 20C. However, slightly sunken or discolored regions continued to degenerate until the affected area was completely necrotic.

Harvesting sweet basil in the second half of the day significantly improved the visual shelf life only for storage temperatures $\geq 10 \mathrm{C}$ (Fig. 3 ). There was a nearly two-fold increase in

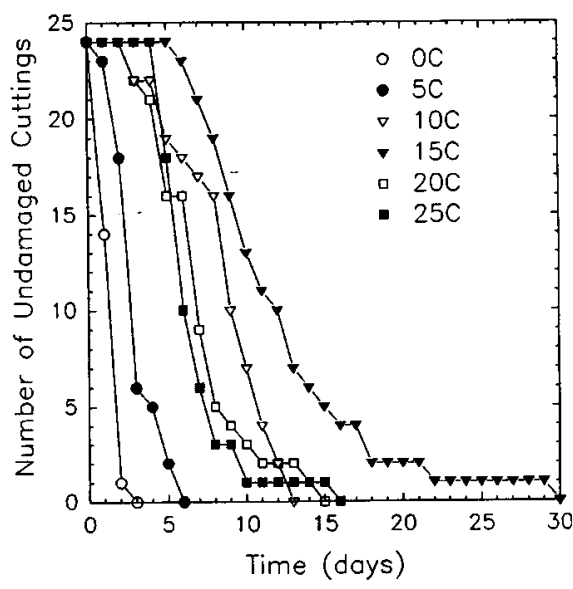

Fig. 1. The effect of temperature on the number of undamaged packaged sweet basil cuttings over time. Cuttings were classified as damaged if there were any observable lesions. The total number of cuttings for each temperature treatment was 24 .

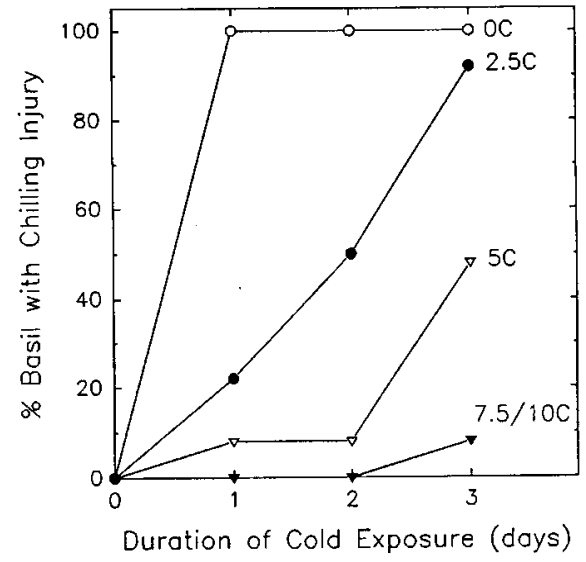

Fig. 2. Development of chilling injury symptoms on packaged sweetbasil with increasing time of exposure at low temperatures while stored in the dark.

shelf life of sweet basil harvested at $1800 \mathrm{HR}$ compared with 0200 or 0600 HR when held at 10 or 20C. This effect of time of day of harvest was also substantial at $15 \mathrm{C}$, with an increase in shelf life of $170 \%$.

Surprisingly, no alleviation of CI symptoms was observed on shoots from basil stored at 0,5 , or $10 \mathrm{C}$ when harvested at times later in the light period, as was reported for tomato seedlings (King et al., 1982). The difference in response may relate to the use of intact vs. detached plant material, or may represent a basic difference in plant response. In a separate experiment, 24 out of 24 unprotected plants exposed to $5 \mathrm{C}$ developed CI symptoms within 1 day, compared to 3 days for packaged shoots. Protection from heat loss and water loss through the polyethylene packages may have affected the response. Wilson (1976) reported that CI on green bean (Phaseolus vulgaris L.) plants was prevented for 7 to 10 days simply by enclosing the plants in polyethylene bags. The symptoms of CI in green bean plants were wilting and pitting of leaf tissue, which are enhanced by water loss. In our experiments, there was little modification of $\mathrm{O}_{2}$ or $\mathrm{CO}_{2}$ in the packages (data not shown).

The observation that shelf life of cut sweet basil harvested later in the day was greatly improved at 15 to $25 \mathrm{C}$ suggests that diurnal changes did take place. Whether these changes were related to carbohydrate accumulation, as suggested by King et al. (1988), or other factors, was not determined. Whatever the changes, they did not enhance resistance to chilling injury.

There was no evidence that the packaged sweet basil lost an appreciable amount of essential oil during extended storage at $\geq 15 \mathrm{C}$, although no chemical tests were conducted. Leaves retained their characteristic odor and flavor.

The longest shelf life of sweet basil was found at $15 \mathrm{C}$. In contrast to the report of Joyce et al. (1986), CI symptoms were noted at 10C and were severe at $\leq 5 \mathrm{C}$. Possibly, the "optimum" storage temperature may be just above $10 \mathrm{C}$, although this was not tested in this study.

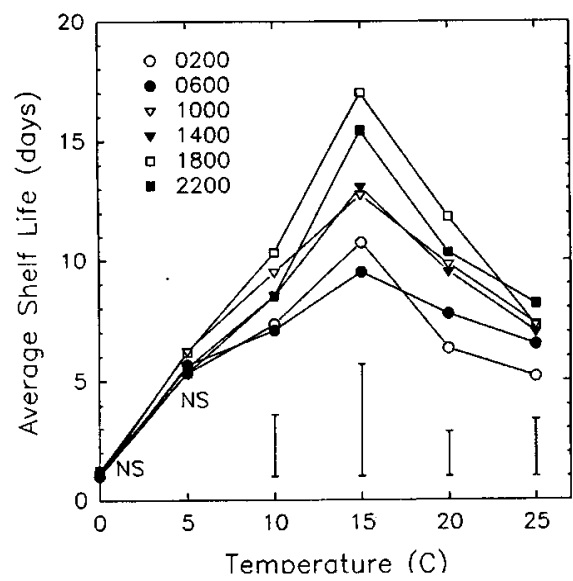

Fig. 3. The effect of time of day of harvest and temperature on the average shelf life of packaged sweet basil stored in the dark. The bars represent the $\mathrm{HSD}_{0.05}$ for treatment mean separation at each temperature. Harvest times were 0200 to $2200 \mathrm{HR}$.

Preharvest temperatures could alter the chilling sensitivity of harvested shoots, which could explain the differences between the current results and those of Joyce et al. (1986).

Perforated polyethylene packages were used in these experiments to limit water loss, as suggested by Joyce et al. (1986) and practiced commercially. In separate experiments, we found that sweet basil readily took up water when the cut stems were placed in water. At 15 to $25 \mathrm{C}$, root initials were observed on the lower portions of the basil stems after holding them in water or polyethylene packages after 1 to 2 weeks.

The results from this study suggest that, for maximum shelf life, sweet basil should be harvested near the end of the light period and stored above $10 \mathrm{C}$ with protection from water loss. When bruising and other damage was avoided, shelf life of sweet basil was nearly 2 weeks. Shelf life was found to be longer at 20 and $25 \mathrm{C}$ than at 0 and $5 \mathrm{C}$, although 1-to 2-day exposures to $5 \mathrm{C}$ could be tolerated with no observable CI symptoms.

\section{Literature Cited}

Hardenburg, R. E., A.E. Watada, and C.Y. Yang. 1986. The commercial storage of fruits, vegetables, and florist and nursery stocks. U.S. Dept. of Agriculture Agr. Hdbk. 66 (rev.).

Joyce, D. C., M.S. Reid, and P. Katz. 1986. Postharvest technology of fresh horticultural crops. Cooperative Extension, Univ. of California, Issue 58.

King, A. I., DC. Joyce, and M.S. Reid. 1988. Role of carbohydrates in diurnal chilling sensitivity of tomato seedlings. Plant Physiol. 86:764-768.

King, A.I., M.S. Reid, and B.D. Patterson. 1982. Diurnal changes in the chilling sensitivity of seedlings. Plant Physiol. 70:211-214.

Saltveit, M. E., Jr., and L.L. Morris. 1990. Overview on chilling injury of horticultural crops, p. 3-16. In: C.Y. Wang (ed.). Chilling injury of horticultural crops. CRC Press, Boca Raton, Fla.

Wilson, J.M. 1976. The mechanism of chill- and drought-hardening of Phaseolus vulgaris leaves. New Phytol. 76:257-270. 